\title{
Imprints of liberalisation, privatisation and globalisation on third world economies with focus on India
}

\author{
M.K. Bhandari \\ JaiNarayan Vyas University, \\ Jodhpur-342003, India \\ E-mail: profmkb.law@gmail.com
}

\begin{abstract}
The entire world is stirred due to the emergence of liberalisation, privatisation and globalisation (hereinafter termed as LPG). Amidst contradictions and controversies, the World Trade Organization (WTO), has further accelerated the process. The process of globalisation coupled with related phenomenon of privatisation and liberalisation today seems to be impacting the Indian socio-economic scenario down to the level of the small towns and villages. Since the last two decades, the process of globalisation and the opening up of market economy have given rise to many philosophical ${ }^{1}$ and policy crises, especially in the context of developing economies. ${ }^{2}$ The paper seeks to assess and analyse the negative foot prints, such as concentration of wealth in few private players, steep rise in corruption, crisis of food security and environmental degradation. An attempt is made to come out with some viable solutions so as to make globalisation more meaningful.
\end{abstract}

Keywords: globalisation; liberalisation; privatisation; developing economy; India; corruption; food security; challenges.

Reference to this paper should be made as follows: Bhandari, M.K. (2013) 'Imprints of liberalisation, privatisation and globalisation on third world economies with focus on India', Int. J. Liability and Scientific Enquiry, Vol. 6, Nos. 1/2/3, pp.125-131.

Biographical notes: M.K. Bhandari is a Senior Professor of Law and former Head and Dean. He has teaching and research experience of 35 years. He is Legal Advisor of IPR Cell. His publications include six books, 40 research papers in national and international journals and two research projects completed. He is a Research Guidance for post doctoral and doctoral work to 20 research scholars, and a Visiting Faculty in nearly ten universities in India. He has participated in 14 international conferences at London, Viena, Geneva, Athanes, China and in nearly 60 national seminars. He is a Fellow of Salzburg Seminar Austria and Indian Law Institutes Delhi-India. He has produced and directed 35 educational films on subjects, viz., human rights, legal aids, UN and India and IPR.

This paper is a revised and expanded version of a paper entitled 'Imprints of liberalisation, privatisation and globalisation on third world economies with focus on India' presented at IIATL Conference, Athens, Greece, 2-4 October 2012. 


\section{Introduction}

The world is stirred due to the emergence of liberalisation, privatisation and globalisation (hereinafter termed as LPG). Amidst contradictions and controversies, the World Trade Organization - WTO has further accelerated the process.

The theme song of LPG is to create competition and allow market forces to play their free hand with minimal state intervention. The emerging policies and predicaments of LPG have redefined the concept, nature and the aspects of the State.

The process of Globalisation coupled with related phenomenon of privatisation and liberalisation, today seems to be impacting the Indian socio-economic scenario down to the level of the small towns and villages. ${ }^{3}$ The gains and losses of LPG are percolating down to the towns and villages impacting lives of billions of people.

\section{Concept of globalisation}

Since the last two decades, the processes of globalisation and the opening up of market economy have given rise to many philosophical and policy crisis especially in the context of developing economies. It is because it provides a life-world, i.e., in the form of social reality as well as the world view which initiates several conceptual approaches and theoretical debates to understand globalisation. One of these theoretical approaches relates globalisation with two broad macro processes, i.e. the globalisation of trade and trade culture and the changing nature of labour and gender struggle in the transforming economy. ${ }^{4}$

In common parlance, economic globalisation is nothing but the expansion of the market to encompass the entire globe within its sphere through the opening up of national boundaries allowing freer trade and flows of capital, labour, technology and information to integrate the various regional markets into a world market. The policies, such as, market liberalisation privatisation, trade liberalisation, incentives to foreign direct investment and the worldwide use of micro-electronics in the nineties were instrumental in increasing the permeation of the national economic boundaries. It is during this very period that most of the underdeveloped and the developing countries of Asia, Africa, Latin America and Eastern Europe facing severe economic hardships after a prolonged resistance were actually forced to adopt the structural adjustments thrust upon by the International Monetary Fund (IMF) and the World Bank (WB) as part of the package deal to bail out of the debt crisis. The removal of the trade barriers and rationalisation of tariffs and the principal outcome of the WTO Agreements, led to movements of goods and services, capital and labour on massive scale. These global developments essentially impacted the domestic policies causing further disadvantage to the disadvantaged. ${ }^{5}$

\section{Human right dimension}

The Universal Declaration of Human Rights recognises what have traditionally been seen as two distinct sets of rights: civil and political rights and economic, social and cultural rights. Each set of rights is reflected in a separate Covenant, the International Covenant on Civil and Political Rights ('ICCPR') and the International Covenant on Economic, Social and Cultural Rights ('ICESCR') respectively. ${ }^{6}$ The ICESCR is divided into 
five parts. Part I (like Part I of the ICCPR) recognises the right to peoples to self-determination; Part II defines the general nature of states party's obligations; Part III enumerates the specific substantive right; Part IV deals with international implementation and Part V contains typical final provisions of a human rights treaty. The substantive rights in Part III include the right to work (Article 6), to just and favourable conditions of work (Article 7), to form trade unions (Article 8), to social security and insurance (Article 9) to an adequate standard of living, including food, clothing and housing (Article 11), to physical and mental health (Article 12) and to education (Article 13).

Under the International Human Rights Law, every State has three obligations - the obligation to respect, the obligation to protect and the obligation to fulfil human rights. The obligation to respect requires the State to abstain from doing that which violates, even directly or indirectly, the concerned human right. The obligation to protect requires the State and its agents to take the measures necessary to prevent other individuals or groups from violating or infringing the enjoyment of the right. The obligation to fulfil requires the State to take measures to ensure each person within its jurisdiction has the opportunities to obtain satisfaction of those needs recognised in the human rights instruments which cannot be achieved by personal efforts. All human rights are interdependent, indivisible and inalienable. You take away one, you take away the others. Deny food, deny livelihood, deny shelter and you deny liberty, freedom, and ultimately the right to life and all that goes with life.

\section{Globalisation and third world countries}

It is true that GLP has helped third world countries in several ways. They have been able to pursue necessary economic reforms, exploit their talent pool and resources, but it is equally a harsh reality that these countries which constitute a major population of the entire globe are not getting richer but becoming poorer.

Globalisation theory maintains that all must benefit from recent changes. The Economist, house magazine of the global free marketers, maintains that the world system now delivers 'more for all' and that vigorous growth in the Third World means it is the world's poor who will benefit most. ${ }^{7}$ Every index of economic and social advance, however, suggests otherwise. Among most of the 4.4 billion people living in Africa, Asia and Latin America life has become a more desperate struggle for survival. The United Nations Development Programme (UNDP) estimates that 840 million people are malnourished and the great mass of them living in countries of the Third World. ${ }^{8}$ More than half the countries for which statistics are available do not have enough food to provide all their population with the minimum daily requirement of calories. ${ }^{9}$ In some regions hunger has become far more general across Africa the average household now consumes $25 \%$ less than in the early 1970s. ${ }^{10}$ Between 1995 and 1997 only 21 out of 147 Third World countries recorded per capital growth of over 3\% a year the rate specified by the UN for reduction of poverty. ${ }^{11}$ There are staggering inequalities. California alone has a gross domestic product (GDP) of equal value to that of China and India combined; ${ }^{12}$ the wealth of the world's 15 richest people now exceeds the combined GDP of sub-Saharan Africa; the wealth of the richest 84 individual exceeds the GDP of China, with its 1.2 billion inhabitants. ${ }^{13}$ There is no evidence to suggest that the 'global era' has brought prosperity or even an alleviation of human suffering. On the contrary, even the 
conservative UNDP concludes that the picture is of a backlog of shortfalls and gaping inequalities. ${ }^{14}$

The changing scenario in India in the last two decades of 20th century and the down of 21 st century is witnessing rapid change due to emergence of new policies of globalisation. One of the changing aspects of State in globalised India is adoption of policy of Privatisation. Under the Privatisation the State has either disinvested its own funds from the public sectors or the private individuals have been granted the permission to establish and run the enterprises according to their interests. The private sectors are establishing the industries on the basic services like water, road, railways, electricity, and education. The role of state in the matters of the governance is being minimised and the maximum scope is being endowed with to the private individuals who are capitalists. They are not covered under the definition of state and there is a huge violating the fundamental rights of the citizens. As this policy is market oriented they need not to respect directive principles of state policy. In brief the enforcement of constitutional scheme is evident to become difficult in Privatisation and it is responsible to raise serious social, economic and legal issues. ${ }^{15}$

The setting up of the WTO in 1995 has intensified global competition. The WTO regulates multilateral trade and enforces its member countries to remove import quotas and other import restrictions, and to reduce import tariffs. In addition, countries, especially the developing countries, are asked to stop subsidies to exports as well as to domestic production. As a result, every single individual enterprise in India, small or large, whether exporting or serving the domestic market, has to face competition. ${ }^{16}$

\section{The challenges ahead}

Following are same major changes being posed by the process of LPG,

\subsection{Concentration of wealth}

Wealth condensation is a theoretical process by which, under certain conditions, newly created wealth concentrates in the possession of already - wealthy individuals or entities. According to this theory, those who already hold wealth have the means to invest in new sources of creating wealth or to otherwise leverage the accumulation of wealth, thus are the beneficiaries of the new wealth. Over time, wealth condensation can significantly contribute to the persistence of inequality within society. ${ }^{17}$

\subsection{Economic inequality}

There are many reasons for economic inequality within societies. These causes are often inter-related. Acknowledged factors that impact economic inequality include the labour market, innate ability, education, computerisation, growing technology, economic neo-liberalism, globalisation, wealth condensation and development pattern, personal preference for work. ${ }^{18}$

A major cause of economic inequality within modern market economies is the determination of wages by the market. Inequality is caused by the differences in the supply and demand for different types of work. In a purely capitalist mode of production (i.e., where professional and labour organisations cannot limit the number of workers) the 
workers' wages will not be controlled by these organisations, nor by the employer, but rather by the market. Wages work in the same way as prices for any other good. Thus, wages can be considered as a function of market price of skill. And therefore, inequality is driven by this price. Under the law of supply and demand, the price of skill is determined by a race between the demand for the skilled worker and the supply of the skilled worker. We would expect the price to rise when demand exceeds supply, and vice versa. Employers who offer a below market wage will find that their business is chronically understaffed. Their competitors will take advantage of the situation by offering a higher wage to snatch up the best of their labour. For a businessman who has the profit motive as the prime interest, it is a losing proposition to offer below or above market wages to workers. ${ }^{19}$

\subsection{Food security}

Worldwide around 852 million people are chronically hungry due to extreme poverty, while up to 2 billion people lack food security intermittently due to varying degrees of poverty (source FAO 2003) six million children die of hunger every year 17,000 every day. ${ }^{20}$

The supreme court of India speaking through Justice Dalveer Bhandari (as he then was-now judge, ICJ at Hague) and Justice Deepak Verma observed on how food stock is lying 'rotten' at government godowns without reaching the 'poor and needy' they suggested to the government to free distribute the food stock free to the poor and needy population.

\subsection{Corruption}

Indian Democratic Institutions are facing a threat from corruption. In past 15 years country has witness several major corruption scams. In wake of such wide spread corruption the public at large is getting agitated and raising demand for strong Law (Lokpal) and effective enforcement mechanism. Governance deficit, poor enforcement of existing anticorruption laws and to some extent greed exacerbated due to huge opportunity for private players in the era of LPG has contributed in rise of corruption.

\section{Conclusions}

No society can claim to be a just society, if the majority of people are dying because of hunger, extreme poverty and facing humiliations of various kinds and subjected to multiple kinds of deprivations.

Today's economic jurisprudence is being guided more by market forces and less by state forces. This thrust on market forces has both positive and negative aspects. The positive aspects include the opportunities for the growth of entrepreneurial skills and better market access both at domestic and international level. The most negative element of this economic liberalisation has been the exposed vulnerability of the poor and marginalised sections of the society. But this economic liberalisation is a reality and therefore the question to be asked is how to maximise the opportunities and minimise the negatives?

In the words of Jospeh Stiglitz ${ }^{21}$ 
"Too much is at stake - and there are too many who have already benefited from globalization - to allow America and Europe to pull back from globalization to walk away from it. There are too many losers from globalization in the developing world to allow the developed world to try to shape globalization unfairly in its favour."

That leaves but one course - coping with globalisation and reshaping it. To quote Jospeh Stiglitz again, ${ }^{22}$

"For much of the world, globalization as it has been managed seems like a pact with the devil. A few people in the country become wealthier, GDP statistics, for what they are worth, look better, but ways of life and basic values are threatened. For some parts of the world the gains are even more tenuous, the costs more palpable. Closer integration into the global economy has brought greater volatility and insecurity, and more inequality. It has even threatened fundamental values."

"This is not how it has to be. We can make globalization work, not just for the rich and powerful but for all people, including those in the poorest countries. The task will be long and arduous. We have already waited far too long. The time to begin is now."

On all great subjects much remains to be said.

\section{Notes}

1 Sarkar, S. (2007) 'Globalization and women at work: a feminist discourse', International Feminist Summit, 17-20 July, Australia.

2 Kanth, A.K. and Sahay, A. (2011-2012) Globalization, Vulnerability and Child Labour Indian Contest, Annual report [online] http://www.prayaschildren.org (accessed 15 July 2012).

3 Quoted from: Sarkar, S. (2007) 'Globalization and women at work: a feminist discourse', International Feminist Summit, 17-20 July, Australia.

4 Sarkar, S. (2007) 'Globalization and women at work: a feminist discourse', International Feminist Summit, 17-20 July, Australia.

5 Kanth, A.K. and Sahay, A. (2011-2012) Globalization, Vulnerability and Child Labour Indian Contest, Annual report [online] http://www.prayaschildren.org (accessed 15 July 2012).

6 The ICESCR was adopted by the General Assembly in Res. 2200A (XXI) of 16 December 1966 and entered into force on 3 January 1976.

7 The World in 1998, The Economist, Special Report, December 1997.

8 UNDP (1998) Human Development Report, New York.

9 Caufield, C. (1998) Masters of Illusion: The world Bank and the Poverty of Nations, p.332, London.

10 UNDP, op cit.

11 Ibid.

12 The Independent, 17 November 1998.

13 UNDP, op cit.

14 UNDP, op cit.

15 Pole, K.P. (2010) 'Judicial activism \& the changing name of the state in globalization', International Research Journal, September, Vol. I, p.12, ISSN 0975-3486 RNI RAJBIL 2009/30097. 
16 Indian Economy: Recent Trend of Globalisation, Liberalisation and Indian Informal Sectors [online] http://www.cuts-international.org/cspac-gelis-workshop.htm.

17 Wealth condensation [online] http://en.wikipedia.org/wiki/Economic_inequality.

18 Economic inequality [online] http://en,wikipedia.org/wiki/Economic_inequality.

19 Hazlitt, H. (1988) Economics in One Lesson, December, Three Rivers Press ISBN 978-0517548233.

20 U.N. Chief: Hunger kills 17,000 kids daily - CNN com CNN November 17, 2009 Retrieved May 2, 2010

21 Stiglitz, J. (2006) Making Globalization Work, p.275, Penguine Books, London.

22 Ibid p.292. 